\title{
PENGARUH PERUSAHAAN TERHADAP KEBIJAKAN DIVIDEN PADA PERUSAHAAN MANUFAKTUR YANG TERDAFTAR DI BURSA EFEK INDONESIA
}

\author{
THE INFLUENCE OF THE COMPANY ON DIVIDEND POLICY \\ ON MANUFACTURING COMPANIES LISTED \\ ON THE INDONESIAN STOCK EXCHANGE
}

\author{
Bayu Wulandari ${ }^{1}$, Mettania Kirana ${ }^{2}$, Helnia Oktavia Sitanggang ${ }^{3}$, Jayana ${ }^{4}$ \\ Universitas Prima Indonesia $1,2,3,4$ \\ wulandari.bayu044@gmail.com ${ }^{1}$
}

\begin{abstract}
This research was aimed to evaluate whether there is a Leverage, Total Assets Turnover, Earning per Share, Current Ratio, Profitability, and Firm Size have related to dividend policy of manufacturing companies which is registered on Indonesia stock exchange in period 2017-2019. This research is included in type of quantitative descriptive research which uses data from 162 manufacturing companies that is registered on Indonesia stock exchange in period 2017-2019. This research also uses purposive sampling method that have 52 samples. Data in this research are all of the financial reports from each company that is published on www.idx.co.id. The variables related in this research are leverage, tato, eps, current ratio, profitability, and firm size. The research's method uses descriptive analysis and multiplelinear regression analysis. The result of this study shows that Leverage have a negative effect to dividend policy, Total Assets Turnover have a negative effect to dividend policy, Earning per Share does not have a negative and significant to dividend policy, Current Ratio have a negative effect to dividend policy, Profitability does not make a significant contribution to dividend policy, and Firm Size does not have a negative and significant to dividend policy of manufacturing companies on Indonesia stock exchange. Simultaneously, Leverage, Total Assets Turnover, Earning per Share, Current Ratio, Profitability, and Firm Size together have a significant with dividend policy of manufacturing companies on Indonesia stock exchange.
\end{abstract}

Keywords : Leverage, Total Assets Turnover, Earning per Share, Current Ratio, Profitability, Firm Size, and Dividend Policy.

\begin{abstract}
ABSTRAK
Penelitian ini ditujukan untuk mengevaluasi apakah Leverage, Total Assets Turnover, Earning per Share, Current Ratio, Profitabilitas, dan Ukuran Perusahaan memiliki pengaruh terhadap kebijakan dividen pada perusahaan manufaktur yang terdaftar di Bursa Efek Indonesia periode 2017-2019. Penelitian ini termasuk ke dalam jenis penelitian deskriptif kuantitatif, yang menggunakan data dari 162 perusahaan manufaktur yang terdaftar di Bursa Efek Indonesia. Penelitian ini juga menggunakan metode pengambilan sampel purposive sampling yang memperoleh 52 sampel. Data dalam penelitian ini merupakan laporan keuangan dari setiap perusahaan sampel yang mempublikasikan laporan keuangannya pada situs www.idx.co.id. Mengenai variabel yang berhubungan dengan penelitian ini adalah Leverage, Total Assets Turnover,
\end{abstract}


Earning per Share, Current Ratio, Profitabilitas, dan Ukuran Perusahaan. Metode penelitian yang digunakan merupakan metode analisis deskriptif dan metode analisis regresi linear berganda. Hasil dari penelitian ini menerangkan bahwa secara simultan Leverage memiliki pengaruh negatif terhadap Kebijakan Dividen, Total Assets Turnover memiliki pengaruh negatif terhadap Kebijakan Dividen, Earning per Share tidak berpengaruh negatif dan signifikan terhadap Kebijakan Dividen, Current Ratio memiliki pengaruh negatif terhadap Kebijakan Dividen, Profitabilitas tidak berpengaruh signifikan terhadap Kebijakan Dividen, dan Ukuran Perusahaan tidak berpengaruh negatif dan signifikan terhadap Kebijakan Dividen yang terdaftar di Bursa Efek Indonesia. Secara simultan Leverage, Total Assets Turnover, Earning per Share, Current Ratio, Profitabilitas dan Ukuran Perusahaan berpengaruh terhadap Kebijakan Dividen pada perusahaan manufaktur yang terdaftar di Bursa Efek Indonesia.

Kata Kunci : Leverage, Total Assets Turnover, Earning per Share, Current Ratio, Profitabilitas, Ukuran Perusahaan, dan Kebijakan Dividen.

\section{PENDAHULUAN}

Dalam perusahaan pasti mempunyai tujuan untuk mendapatkan laba sebesar mungkin secara efisien. Seorang investor biasanya tertarik untuk menanamkan modalnya pada perusahaan dengan laba tinggi. Dimana adanya kebijakan dividen, yaitu keputusan perusahaan dalam membagikan dividen kepada para pemegang saham yang ditentukan dari besarnya laba yang diperoleh.

Perusahaan dengan leverage yang tinggi menunjukkan kewajiban perusahaan yang besar sehingga dividen yang dibagikan akan lebih kecil. Selain itu, perputaran aktiva pada perusahaan yang tinggi menunjukkan efesiensi kemampuan perusahaan guna memaksimalkan laba. Perusahaan dengan Earning Per Share (EPS) yang besar menjadi ketertarikan investor karena hal ini menunjukkan keberhasilan perusahaan untuk memperoleh profit.

Perusahaan mempunyai tingkat likuiditas yang tinggi menunjukkan adanya kewajiban jangka pendek perusahaan yang besar sehingga dividen yang harus dibagikan oleh perusahaan semakin besar. Suatu perusahaan dengan tingkat profitabilitas tinggi tentunya mempunyai dividen yang besar yang akan dibagikan kepada para pemegang saham. Perusahaan besar cenderung memiliki profitabilitas yang tinggi sehingga pembayaran dividen dapat dibagikan dengan jumlah lebih besar dibanding dengan perusahaan kecil. Perusahaan besar cenderung menarik perhatian para investor dalam menanamkan modalnya.

Perusahaan manufaktur mengalami perkembangan pesat di perekonomian Indonesia. Sampel yang digunakan dalam penelitian ini adalah perusahaan manufaktur yang terdaftar di Bursa Efek Indonesia periode 20172019.

Beberapa fenomena terjadi pada perusahaan manufaktur di BEI periode tahun 2017-2019, di antaranya : PT. Wijaya Karya Beton Tbk persentase total hutang tahun 2017 dan 2018 mengalami peningkatan sebesar $\mathrm{Rp}$ 1.424.925.528.509 dan persentase dividen tahun 2017 dan 2018 mengalami peningkatan sebesar Rp 19.428.258.155. Fenomena ini bertolak belakang dengan teori yang ada yaitu apabila total hutang naik maka pembagian dividen akan menurun. Fluktuasi terjadi pada PT. Pelangi Indah Canindo Tbk persentase penjualan 
tahun 2018 dan 2019 mengalami penurunan sebesar $\mathrm{Rp}$ 5.884.752.737 dan persentase dividen tahun 2018 dan 2019 mengalami peningkatan sebesar Rp 1.673.655.000. Fenomena ini bertolak belakang dengan teori yang ada yaitu apabila penjualan menurun maka dividen yang dibagikan juga akan menurun.

Selanjutnya data fluktuasi pada PT. Trisula International Tbk presentase jumlah saham yang beredar tahun 2018 dan 2019 mengalami kenaikan sebesar Rp. 1.200.000.000, presentase dividen tahun 2018 dan 2019 mengalami penurunan sebesar Rp.3.140.784.006. Fenomena ini bertolak belakang dengan teori yang ada yaitu apabila saham yang beredar naik maka dividen juga naik tetapi pada perusahaan tersebut saham yang beredar naik tetapi dividen turun. Data fluktuasi pada PT. Malindo Feedmill Tbk presentase asset lancar tahun 2017 dan 2018 mengalami kenaikan sebesar Rp. 187.469.410.000 dan untuk presentase dividen tahun 2017 dan 2018 mengalami penurunan sebesar Rp. 49.252.500.000. Fenomena ini bertolak belakang dengan teori yang ada yaitu apabila asset lancar naik maka dividen juga akan naik tetapi pada perusahaan PT. Malindo Feedmill Tbk mengalami penurunan pada dividen sedangkan asset lancarnya mengalami kenaikan.

Data fluktuasi pada Ultra Jaya Milk Industry and Trading Company Tbk persentase laba bersih 2017 dan 2018 mengalami penurunan $\mathrm{Rp}$ 10.074.000.000 dan persentase dividen 2017 dan 2018 mengalami kenaikan Rp 41.359.000.000. Fenomena ini bertolak belakang dengan teori yang ada yaitu apabila laba bersih menurun maka dividen yang dibagikan juga akan ikut menurun. Terakhir, data fluktuasi pada Hanjaya Mandala Sampoerna Tbk persentase total aset 2017 dan 2018 mengalami kenaikan Rp 3.461.357.000.000, sedangkan persentase dividen 2017 dan 2018 mengalami penurunan $\mathrm{Rp}$ 46.527.000.000. Fenomena ini bertolak belakang dengan teori yang ada yaitu apabila total asset naik maka dividen yang dibagikan juga akan naik.

Menurut Kasmir (2016),

Leverage menujukkan kemampuan perusahaan memanfaatkan utang untuk membiayai aktiva perusahaan. Rasio tersebut mengukur kemampuan perusahaan dalam memenuhi kewajibannya yaitu semakin tinggi nilai rasio menunjukkan semakin besar resiko pada perusahaan yang memungkinkan tingkat pengembalian (dividen) yang tinggi.

Total Aset Turnover adalah rasio aktivitas yang mengukur penggunaan seluruh aktiva dalam perusahaan secara efisien untuk menghasilkan penjualan. TATO yang meningkat menunjukkan penggunaan seluruh asset perusahaan dengan sangat efisien dalam meningkatkan penjualan sehingga dividen yang diperoleh juga akan meningkat.

Earning Per Share adalah hak setiap pemegang saham biasa untuk mendapatkan laba. Pada dasarnya, laba merupakan penentu pembayaran dividen dan menentukan kenaikan nilai saham.

Menurut Kasmir (2016), Current Ratio yaitu rasio untuk mengukur kemampuan perusahaan dalam membayar kewajiban jangka pendeknya yang akan jatuh tempo. Ataupun, seberapa banyak aktiva lancar menutupi kewajiban jangka pendeknya dengan efektif maka menunjukkan perusahaan likuid dan dapat menghasilkan laba sehingga semakin besar pula perusahaan mampu untuk membayar dividennya.

Menurut Kasmir (2016), profitabilitas merupakan rasio yang 
mengukur kemampuan perusahaan untuk memperoleh profit. Tingkat profitabilitas perusahaan yang tinggi menunjukkan laba yang diperoleh semakin besar dimana pembagian dividen terhadap pemegang saham juga semakin tinggi. Silaban \& Purnawati (2016), menyatakan bahwa profitabilitas memberikan pengaruh positif dan signifikan terhadap kebijakan dividen.

Besar kecilnya ukuran perusahaan turut menentukan kemampuan perusahaan dalam menanggung resiko. Tolak ukur dalam menentukan besar kecilnya ukuran perusahaan dilihat dari banyaknya aktiva perusahaan tersebut (Wimelda \& Marlinah 2013). Sehingga ukuran perusahaan yang besar dapat membagikan dividen lebih besar dibanding dengan ukuran perusahaan yang kecil karena perusahaan dengan asset yang besar dapat dengan mudah untuk bersaing di pasar modal.

Damayanti, et.al (2017), kebijakan dividen merupakan keputusan perusahaan dalam menentukan laba yang akan dibagikan kepada para pemegang saham dan jumlah laba ditahan untuk investasi perusahaan. Perusahaan yang memiliki kebijakan dividen yang bagus akan menghindari terjadinya fluktuasi dividen karena akan mempengaruhi harga saham.

\section{METODE PENELITIAN Populasi}

Populasi adalah seluruh subjek yang dianalisis dalam penelitian. Populasi yang dianalisis dalam penelitian adalah seluruh perusahaan manufaktur yang terdaftar di Bursa Efek Indonesia (BEI).

\section{Sampel}

Sampel adalah bagian dari populasi yang menjadi gambaran bagi populasi asalnya. Teknik pengambilan sampel penelitian adalah purposive sampling. Purposive sampling adalah teknik penentuan sampel dengan menetapkan ciri-ciri khusus yang sesuai dengan tujuan penelitian.

Tabel 1. Pemilihan Sampel

\begin{tabular}{llc}
\hline No. & \multicolumn{1}{c}{ Keterangan } & Jumlah \\
\hline 1. & $\begin{array}{l}\text { Perusahaan Manufaktur yang } \\
\text { terdaftar di Busa Efek Indonesia } \\
\text { periode 2017-2019 }\end{array}$ & 162 \\
\hline & $\begin{array}{l}\text { Perusahaan Manufaktur yang } \\
\text { laporan keuangan nya tidak terdaftar } \\
\text { di Bursa Efek Indonesia periode } \\
\text { 2017-2019 }\end{array}$ \\
2. & $(34)$ \\
Perusahaan Manufaktur yang \\
mengalami kerugian pada Bursa \\
Efek Indonesia periode 2017-2019
\end{tabular}

Sumber : Data di olah (2019)

Total jumlah data pada sampel yang digunakan dalam penelitian ini yaitu sebanyak 156 data pengamatan, yang diambil dari jumlah sampel 52 perusahaan dikalikan dengan 3 tahun penelitian.

\section{Model Penelitian}

Dalam penelitian ini, metodeanalisis data yang digunakan adalah metode analisis statistik. Sebelum analisis data, maka dilakukan uji asumsi klasik terlebih dahulu sebelum menguji hipotesis. Analisis data dalam mengelolah data menggunakan SPSS (Statistical Product and Service Solution).

Model analsisis data ini menggunakan analisis regresi berganda untuk mengetahui pengaruh variable bebas (independen) dan variabel terikat (dependen) digunakan rumus analisis regresi linier berganda sebagai berikut:

$$
\begin{gathered}
\mathrm{Y}=\mathrm{a}+\mathrm{b} 1 \mathrm{X} 1+\mathrm{b} 2 \mathrm{X} 2+\mathrm{b3X3}+ \\
\text { b4X4+b5X5+b6X6+e }
\end{gathered}
$$


Keterangan:

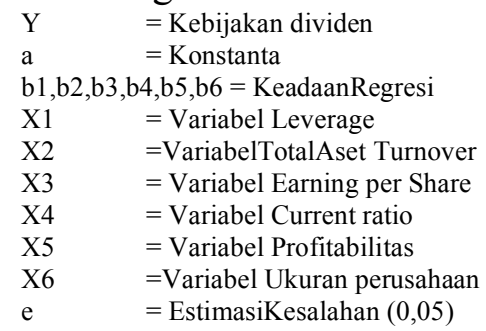

\section{Pengujian Hipotesis Secara Simultan}

Uji statistik $F$ digunakan untuk menunjukkan apakah semua variable independen dalam model mempunyai pengaruh secara bersama-sama terhadap variable dependen. Adapun cara mengujinya dengan hipotesis ini adalah sebagai berikut: Untuk menguji hipotesis ini digunakan statistik $\mathrm{F}$ dengan criteria pengambilan keputusan yang membandingkan nilai $F$ hasil perhitungan dengan nilai $\mathrm{F}$ menurut tabel, yaitu:

$H_{O}$ diterima atau $H_{a}$ ditolak jika

$F_{\text {hitung }} \leq F_{\text {tabel }}$ dan nilai sig $>0,05$

$H_{a}$ diterima atau $H_{o}$ ditolak jika

$F_{\text {hitung }}>F_{\text {tabel }}$ dan nilai sig $<0,05$

\section{Pengujian Hipotesis Secara Parsial}

Uji Statistik T digunakan untuk menunjukkan pengaruh variable independen secara individual terhadap variable dependen. Adapun cara mengujinya dengan hipotesis ini adalah sebagai berikut: Cara melakukan uji $\mathrm{t}$ adalah dengan membandingkan nilai statistik $\mathrm{t}$ dengan titik kritis menuru $\mathrm{t}$ tabel. Apabilanilai statistic $\mathrm{t}$ hasil perhitungan lebih tinggi dibandingkan nilai $\mathrm{t}$ tabel, maka dapat menerima hipotesis alternative menyatakan bahwa suatu variable independen secara individual mempengaruhi variable independen. Kriteria ini dapat disimpulkan menjadi:
$H_{O}$ diterima atau $H_{a}$ ditolak jika

$t_{\text {hitung }} \leq t_{\text {tabel }}$ dan nilai sig $>0,05$

$H_{a}$ diterima atau $H_{o}$ ditolak jika

$t_{\text {hitung }}<t_{\text {tabel }}<t_{\text {hitung }}$ dan nilai sig $<0,05$.

\section{HASIL DAN PEMBAHASAN Model Penelitian}

Dalam melaksanakan pengujian hipotesisnya digunaka cara analisa regresi linier berganda. Model regresi yang dipakai yaitu;

Tabel 2.Hasil Analisis Regresi Linear Berganda

\begin{tabular}{|c|c|c|c|}
\hline \multirow[b]{2}{*}{ Model } & \multicolumn{2}{|c|}{$\begin{array}{c}\text { Unstandardized } \\
\text { Coefficients }\end{array}$} & \multirow{2}{*}{$\begin{array}{c}\begin{array}{c}\text { Standard } \\
\text { ized } \\
\text { Coefficie } \\
\text { nts }\end{array} \\
\text { Beta } \\
\end{array}$} \\
\hline & B & $\begin{array}{l}\text { Std. } \\
\text { Error }\end{array}$ & \\
\hline 1 (Constant) & -27.253 & 5.414 & \\
\hline LN_Leverage & -.204 & .104 & -.092 \\
\hline LN_TATO & .079 & .206 & .014 \\
\hline LN_EPS & .932 & .051 & .793 \\
\hline LN_CR & -.275 & .178 & -.073 \\
\hline $\begin{array}{l}\text { LN_UkuranPerusah } \\
\text { aan }\end{array}$ & 7.883 & 1.619 & .183 \\
\hline LN_ROA & .008 & .096 & .003 \\
\hline
\end{tabular}

Berdasarkan Tabel 2 diatas, maka rumus regresinya adalah:

DPS $=(-27,253)+(-204)$ Leverage + 0,079 TATO + 0,932 EPS + (-0,275) CR $+7,883$ Ukuran Perusahaan + 0,008 ROA

1. Nilai a sebesar $(-27,253)$ satuan menyatakan bahwa jika variabel Leverage, Total Assets Turnover (TATO), Earning per Share (EPS), Current Ratio, Ukuran Perusahaan dan Return on Asset (ROA) bernilai nol maka Dividen per Share (DPS) adalah sebesar $(-27,253)$ satuan.

2. Nilai koefisien variabel Leverage sebesar $(-0,204)$ satuan dan bernilai 
positif menyatakan bahwa setiap kenaikan Leverage 1 satuan akan menyebabkan penurunan Dividend per Share (DPS) sebesar 0,204 satuan.

3. Nilai koefisien variabel Total Asset Turnover (TATO) sebesar 0,079 satuan dan bernilai positif menyatakan bahwa setiap kenaikan Total Asset Turnover (TATO) 1 satuan akan menyebabkan kenaikan Dividend per Share (DPS) sebesar 0,079 satuan.

4. Nilai koefisien variabel Earning per Share (EPS) sebesar 0,932 satuan dan bernilai positif menyatakan bahwa setiap kenaikan Earning per Share (EPS) 1 satuan akan menyebabkan kenaikan Dividend per Share (DPS) sebesar 0,932 satuan.

5. Nilai koefisien variabel Current Ratio (CR) sebesar $(-0,275)$ satuan dan bernilai positif menyatakan bahwa setiap kenaikan Current Ratio (CR) 1 satuan akan menyebabkan penurunan Dividend per Share (DPS) sebesar 0,275 satuan.

6. Nilai koefisien variabel Ukuran Perusahaan sebesar 7,883 satuan dan bernilai positif menyatakan bahwa setiap kenaikan Ukuran Perusahaan 1 satuan akan menyebabkan kenaikan Dividend per Share (DPS) sebesar 7,883 satuan.

7. Nilai koefisien variabel Return on Asset (ROA) sebesar 0,008 satuan dan bernilai positif menyatakan bahwa setiap kenaikan Return on Asset (ROA) 1 satuan akan menyebabkan kenaikan Dividend per Share (DPS) sebesar 0,008 satuan.

\section{Koefisien Determinasi hipotesis}

Koefisien determinasi diterapkan dalam mengidentifikasi besarnya kemampuan model penelitian dalam memaparkan variabel dependent. Jika koefisien determinasinya $\left(\mathrm{R}^{2}\right)$ makin tinggi atau hampir mencapai angka 1, jadi dapat dinyatakan jika kekuatan variabel independennya (X) adalah kuat terhadap variabel dependennya (Y).

\section{Tabel 3 Uji Koefisien Determinasi}

\begin{tabular}{lcccr}
\hline Model & $\mathrm{R}$ & $\begin{array}{c}\mathrm{R} \\
\text { Square }\end{array}$ & $\begin{array}{c}\text { Adjusted R } \\
\text { Square }\end{array}$ & $\begin{array}{r}\text { Std. Error of } \\
\text { the Estimate }\end{array}$ \\
\hline 1 & $.918^{\mathrm{a}}$ & .843 & .836 & .91871 \\
\hline Sumber : Data di olah (2019)
\end{tabular}

Tabel 3 di atas menunjukkan analisis Koefisien Determinasi didapat angka Adjusted $\mathrm{R}$ Square koefisien determinasinya 0,836 maksudnya $83,6 \%$ dari variasi variabel dividend per share yang bisa diterangkan variabel bebas leverage, TATO, EPS, CR, ukuran perusahaan dan ROA 16,4\% diterangkan oleh variabel independen lain yang tidak teliti didalam penelitian ini contohnya total hutang, modal, penjualan, dan lainnya.

\section{Pengujian Hipotesis Secara Simultan}

Uji $F$ dapat dipakai dalam memperlihatkan kesemua variabel independent mempengaruhi secara bersamaan pada variabel depedennya. Hasil dari pngolahan data menggunakan SPSS tersaji sebagai berikut:

Tabel 4 Hasil Uji Statistik F

\begin{tabular}{lcccccc}
\hline Model & $\begin{array}{c}\text { Sum of } \\
\text { Squares }\end{array}$ & df & $\begin{array}{c}\text { Mean } \\
\text { Square }\end{array}$ & F & Sig. \\
\hline 1 & Regression & 673.672 & 6 & 112.279 & 133.027 & $.000^{a}$ \\
\cline { 2 - 6 } & Residual & 125.760 & 149 & .844 & & \\
\hline Total & 799.432 & 155 & &
\end{tabular}


Tabel tersebut memperlihatkan bahwa nilai Fhitungnya 133,027 dan nilai Ftabelnya nilai signifikan 0,05 dan dilihat df1 dan df2 nya dengan rumus $\mathrm{df} 1=\mathrm{k}-1=(6+1)-1=6$, df2 $=\mathrm{n}-\mathrm{k}=$ $156-6=150$ yaitu 2,16 , maka nilai Fhitung $>$ Ftabel $(133,027>2,16)$ sehingga hasil penelitian menolak Ho dan menerima $\mathrm{Ha}$ serta nilai signifikansinya $\leq 0,05$. Sehingga variabel Leverage, Total Assets Turnover (TATO), Earning per Share (EPS), Current Ratio, Ukuran Perusahaan dan Return on Asset (ROA) memberikan pengaruh signifikan pada kebijakan dividen perusahaan manufaktur yang tercatat di BEI periode 2017-2019.

\section{Pengaruh Leverage Terhadap Kebijakan Dividen}

Leverage mempunyai nilai $t_{\text {tabel }}$ sebesar $(-0,204)$ dan nilai $t_{\text {hitung }}$ sebesar 1,976 , maka $(-0,204)<$ 1,976 sehingga $H_{O}$ diterima dan $H_{a}$ ditolak dngan nilai signifikan 0,052 > 0,05 sehingga Leverage berpengaruh dan signifikan terhadap kebijakan dividen (DPS) pada perusahaan manufaktur di Bursa Efek Indonesia periode 2017-2019. Hasil penelitian ini sejalan dengan penelitian Mawarni \& Ratnadi (2014) yang menyatakan leverage berpengaruh negatif dan signifikan terhadap kebijakan dividen sehingga semakin tinggi leverage menunjukkan semakin rendah kemampuan perusahaan membayar dividen.

\section{Pengaruh Total Assets Turnover (TATO) Terhadap Kebijakan Dividen}

Total Assets Turnover (TATO) mempunyai nilai $t_{\text {tabel }}$ sebesar 0,385 dan nilai $t_{\text {hitung }}$ sebesar 1,976 , maka $0,385<1,976$ sehingga $H_{O}$ diterima dan $H_{a}$ ditolak dengan nilai signifikan $0,701>0,05$ sehingga Total Assets Turnover (TATO) berpengaruh dan signifikan terhadap kebijakan dividen (DPS) pada perusahaan manufaktur yang terdaftar di Bursa Efek Indonesia periode 2017-2019. Hasil penelitian ini sejalan dengan dengan replikasi penelitian Rahmawati (2014) yang menyatakan bahwa Total Assets Turnover (TATO) secara simultan berpengaruh negatif terhadap kebijakan dividen. Artinya setiap kenaikkan Total Aset Turn Over (TATO) akan menyebabkan dividen turun. Sehingga apabila Total Aset Turn Over (TATO) turun akan berdampak pada keuntungan yang kecil bagi perusahaan sehingga dividen yang akan dibagikan juga akan rendah.

\section{Pengaruh Earning per Share (EPS) Terhadap Kebijakan Dividen}

Earning per Share (EPS) mempunyai nilai $t_{\text {tabel }}$ sebesar 18,409 dan nilai $t_{\text {hitung }}$ sebesar 1,976 , maka 18,409 > 1,976 sehingga $H_{O}$ ditolak dan $H_{a}$ diterima dengan nilai signifikan $0,000<0,05$ sehingga Earning per Share (EPS) berpengaruh dan signifikan terhadap kebijakan dividen (DPS) pada perusahaan manufaktur yang terdaftar di Bursa Efek Indonesia periode 20172019. Hasil penelitian ini sejalan dengan replikasi penelitian Sarmento \& Dana (2016) yang menyatakan bahwa EPS berpengaruh positif namun tidak signifikan terhadap kebijakan dividen. Artinya EPS merupakan dasar penentu untuk mendapatkan keuntungan dan dalam meningkatkan nilai saham, sehingga apabila EPS naik berdampak pada jumlah laba per saham dan semakin besar dividen yang akan dibagikn kepada para pemegang saham. 


\section{Pengaruh Current Ratio Terhadap Kebijakan Dividen}

Current Ratio (CR)

mempunyai nilai $t_{\text {tabel }}$ sebesar $(-1,546)$ dan nilai $t_{\text {hitung }}$ sebesar 1,976 , maka ($1,546)<1,976$ sehingga $H_{O}$ diterima dan $H_{a}$ ditolak dengan nilai signifikan $0,124>0,05$ sehingga Current Ratio (CR) berpengaruh dan signifikan terhadap kebijakan dividen (DPS) pada perusahaan manufaktur yang terdaftar di Bursa Efek Indonesia periode 20172019. Hasil penelitian ini tidak sejalan dengan replikasi penelitian Sari \& Sudjarni (2015) yang menyatakan bahwa current ratio berpengaruh positif signifikan terhadap kebijakan dividen pada perusahaan. Artinya perusahaan yang mampu menjaga likuiditas perusahaanya dapat memiliki kesempatan untuk membagikan dividennya.

\section{Pengaruh Ukuran Perusahaan Terhadap Kebijakan Dividen}

Ukuran Perusahaan

mempunyai nilai $t_{\text {tabel }}$ sebesar 4,868 dan nilai $t_{\text {hitung }}$ sebesar 1,976 , maka $4.868>1,976$ sehingga $H_{O}$ ditolak dan $H_{a}$ diterima dengan nilai signifikan $0,000<0,05$ sehingga Ukuran Perusahaan berpengaruh dan signifikan terhadap kebijakan dividen (DPS) pada perusahaan manufaktur yang terdaftar di Bursa Efek Indonesia periode 20172019. Hasil penelitian ini sejalan dengan sejalan dengan penelitian yang dilakukan Apriliani \& Natalylova (2017) yang menyatakan ukuran perusahaan menunjukkan hubungan yang positif dan signifikan terhadap kebijakan dividen dimana perusahaan besar memiliki kemudahan akses untuk masuk ke pasar modal dan hal ini akan mengundang para investor untuk menginvestasikan pada perusahaan, sehingga akan mengurangi ketergantungan perusahaan pada pendanaan yang bersumber dari saldo laba ditahan.

\section{Pengaruh Return on Assets (ROA) Terhadap Kebijakan Dividen}

Return on Assets (ROA) mempunyai nilai sebesar 0.087 dan nilai sebesar 1,976, maka $0,087<1,976$ sehingga diterima dan ditolak dengan nilai signifikan $0,931>0,05$ sehingga Return on Assets (ROA) berpengaruh dan signifikan terhadap kebijakan dividen (DPS) pada perusahaan manufaktur yang terdaftar di Bursa Efek Indonesia periode 2017-2019. Hasil penelitian ini sejalan dengan tidak sesuai dengan penelitian yang dilakukan Apriliani \& Natalylova (2017) yang menunjukkan hubungan positif dan signifikan terhadap kebijakan dividen, dimana semakin tinggi ROA yang dimiliki oleh perusahaan, maka dividen yang akan dibayarkan oleh perusahaan juga semakin tinggi.

\section{PENUTUP}

\section{Kesimpulan}

1. Leverage secara parsial berpengaruh negatif terhadap kebijakan dividen pada perusahaan manufaktur yang terdaftar di BEI periode 2017-2019.

2. Total Assets Turnover (TATO) secara simultan berpengaruh negatif terhadap kebijakan dividen pada perusahaan manufaktur yang terdaftar di BEI periode 2017-2019.

3. Earing per Share (EPS) secara parsial mempunyai pengaruh positif dan signifikan terhadap kebijakan dividen pada perusahaan manufaktur yang terdaftar di BEI periode 2017-2019.

4. Current Ratio secara parsial memberikan pengaruh negatif terhadap kebijakan dividen pada perusahaan manufaktur yang terdaftar di BEI periode 2017-2019. 
5. Ukuran Perusahaan secara parsial berpengaruh positif dan signifikan terhadap kebijakan dividen pada perusahaan manufaktur yang terdaftar di BEI periode 2017-2019.

6. Return on Asset (ROA) secara parsial mempunyai pengaruh negatif terhadap kebijakan dividen pada perusahaan manufaktur yang terdaftar di BEI periode 2017-2019.

7. Leverage, Total Assets Turnover (TATO), Earning per Share (EPS), Current Ratio, Ukuran Perusahaan dan Return on Asset (ROA) secara simultan berpengaruh dan signifikan terhadap kebijakan dividen pada perusahaan manufaktur yang terdaftar di BEI periode 2017-2019.

\section{Saran}

Setiap perusahaan manufaktur harus bisa menghasilkan laba sebesar dan seefisien mungkin. Perusahaan harus mampu memanfaatkan hutang dan asetnya dalam menghasilkan laba yang besar untuk meningkatkan dividennya. Dividen dan nilai saham yang besar merupakan daya tarik untuk mendapatkan para investor dalam menanamkan modalnya guna memajukan perusahaannya dan mensejahterakan karyawannya.

\section{DAFTAR PUSTAKA}

Apriliani, A., \& Natalylova, K. (2017). Faktor-faktor mempengaruhi yang dividen pada perusahaan manufaktur di Bursa Efek Indonesia. Jurnal Bisnis dan Akuntansi, 19(1a-1), 49-57.

Damayanti, R., Marwati, F. S., \& Widayanti, R. (2017). Analisa kebijakan dividen berdasarkan teori lintner. AGREGAT: Jurnal Ekonomi dan Bisnis, 1(2), 183194.
Kasmir, (2016). Analisis Laporan Keuangan. Cetakan kesembilan, edisi pertama. Jakarta:PT. Rajagrafindo Persada.

Mawarni, L. F. I., \& Ratnadi, N. M. D. (2014). Pengaruh Kesempatan Investasi, Leverage, dan Likuiditas pada Kebijakan Dividen Perusahaan Manufaktur yang terdaftar di BEI. E-Jurnal Akuntansi, 9(1), 200-208.

Rahmawati, N. D., Saerang, I. S., \& Van Rate, P. (2014). Kinerja Keuangan Pengaruhnya terhadap kebijakan dividen pada perusahaan BUMN di Bursa Efek Indonesia. Jurnal EMBA: Jurnal Riset Ekonomi, Manajemen, Bisnis dan Akuntansi, 2(2).

Sari, K. A. N., \& Sudjarni, L. K. (2015). Pengaruh likuiditas, leverage, pertumbuhan perusahaan, dan profitabilitas terhadap kebijakan dividen pada perusahaan manufaktur di BEI. E-jurnal Manajemen, 4(10).

Silaban, D. P., \& Purnawati, N. K. (2016). Pengaruh Profitabilitas, Struktur Kepemilikan, Pertumbuhan Perusahaan Dan Efektivitas Usaha Terhadap Kebijakan Dividen Pada Perusahaan Manufaktur. EJurnal Manajemen, 5(2).

Sarmento, J. D. C., \& Dana, M. (2016). Pengaruh Return on Equity, Current Ratio, dan Earning per Share terhadap Kebijakan Dividen Pada Perusahaan Keuangan. E-Jurnal Manajemen, 5(7).

Wimelda, L., \& Marlinah, A. (2013). Variabel-variabel yang mempengaruhi struktur modal pada perusahaan publik sektor non keuangan. Media Bisnis, 5(3), 200-213. 